\title{
Strategic Formulation of Local Resources Management To Reduce Poverty
}

\author{
Wahyuningsih \\ Tadulako University, Indonesia \\ ayu_wningsih@yahoo.com
}

\author{
Husnah \\ Tadulako University, \\ Indonesia \\ Niluh Putu Evvy Rosanty \\ Tadulako University, Indonesia
}

\author{
Rostiati Dg. Rahmatu \\ Tadulako University, Indonesia
}

\begin{abstract}
The objective of this research is to propose strategic formulation of poverty reduction model based on economic empowerment and local resource based management. This study has been conducted in Central Sulawesi Province, Indonesia, using in-depth interview and SWOT analysis methods. This research finds out that potential local resources, in this case is coconut shell briquette charcoal, did not supported by human resources capability to improve its value. Hence, some viable strategies are: first, strengthening partnership between businessman and government as well as universities. Second, developing technology used and market information access to national and international market. Third, enhancing capacity and helping small business and fourth increasing financial management capability in managing small business, business coaching among entrepreneurs, and regulation to increase value added of the product.
\end{abstract}

Keywords: local resources management, strategy, poverty reduction

\section{INTRODUCTION}

The use of local resources as an advantage of competitiveness has become an issue that attracts both academics and practitioners [1]. One concept in developing competitiveness is Resource-Based View (RBV) to manage resources and capabilities strategically. Since the introduction of Resource-Based View (RBV) and its existence in the literature, debates, discussions and research have been done to examine the perspective of this theory. Based on local resources and attention focused on the process of creating competitive advantage, RBV is believed to be the fundamental principle that determines differences in the creation of wealth [2].

The existence of RBV in strategic management suggest that the key drivers and capabilities of a company as one of the resources in achieving competitive advantage [3]. Capabilities and resources possessed to be one of the factors determining competitive position. Further, RBV can be utilized as the starting point used to identify and explain excellence.
The competitive advantage of a company flows by relying on its resources[4]. Some earlier researchers argued that resource-based competitiveness is the most important resource. More valuable, rare, imperfectly imitable and non-substitutable resources than competitors become an important source of increasing competitive advantage [5].

Although many researchers have previously conducted a study on RBV, the research context is still limited to the company. In other words, RBV research has not been widely used in community empowerment that leads to improved welfare. The critical question that remains unanswered are how imperfectly imitable and non-substitutable local resources can contribute to improving the economy of the community so as to reduce poverty.

Donggala Regency has a total area of $28.338 \mathrm{Ha}$ of coconut with an average annual production of 37,745 tons. When the coconut shell is managed using technology that becomes charcoal briquettes, it is believed to increase the added value as a renewable energy that can directly increase people's income and can reduce the poverty level. The coconuts have the opportunity to be developed and become end products that have high economic value, such as shell into shell flour, activated carbon, and charcoal briquettes [6]. Hence, transforming natural resources into products that have high added value and competitive, will empower community to improve their income and develop renewable energy which lead to poverty reduction.

\section{LITERATURE REVIEW}

\section{Local Resource Management}

RBV theory has been developed and studied as the basic for managing local resources to generate competitive advantage [7]. RBV emerges as the concept of core competence to be more focused and measurable to perform internal analysis capability. The key of RBV model is based on identifying basic local resources that are the main foundation for finding and developing core competencies. Core competence is regarded as a capability or expertise which has been identified, 
developed, and used throughout the business, and will be the basis of a long-lasting competitive advantage.

The resources or assets as inputs to production processes, such as capital goods, the capabilities of its workers, patents, finances and talented managers [8]. Generally, resources can be classified into three categories; physical resources, human resources, and organization. One type of resource may not produce a sustainable competitive advantage, and then it will take a combination and a group of integration that resources can achieve competitive advantage.

Resources include all financial, physical, human and cultural assets used by businesses to develop, create, and sell their products or services to customers. Although each region has its local resources, it is not entirely unique and capable for achieving a sustainable competitive advantage. In order to make it unique and add value, an RBV approach provides guideline that resources should meet certain requirements, including difficulty in making, purchasing, substituting, and copying. Hence, unique and imitable local resources which be managed professionally will lead to longlasting competitive advantage.

\section{Poverty}

Poverty is a problem that is characterized by various aspects such as low quality of life, limited adequacy and quality of food, limited and low quality of health care, nutrition, and low quality of education. Poverty is strongly influenced by unproductive habits and culture [9]. In many years, many make their attempt to reduce poverty through the provision of food, health and education services, expansion of employment and so on. It has become general agreement that there is no universally accepted definition of poverty. World Bank reveals poverty in terms of income that households or individuals will need to purchase goods and services deemed necessary to maintain physical and social existence set \$ 370 per person per year (or US \$ 1 per day) as an absolute poverty line in developing countries [10].

According to World Bank, there are two types of poverty. First, absolute poverty, i.e. when a person or group of people lives below a certain poverty line value. Second is relative poverty. This type of poverty only compares the welfare positions of a person or a group of people with other societies in their environment. World Bank defines absolute poverty as living with income below USD \$ 1 per day and intermediate poverty for income below $\$ 2$ per day. The poor criterion here is the minimum energy requirement index of 2,100 calories per capita per day (approximately 2000-2500 calories per day for adult males).According to the UN report, there are 12 components of basic needs: health, food and nutrition, education, working conditions, employment situation, consumption and saving transportation, housing, clothing, recreation and entertainment, social security, and freedom. People who live in poor conditions being mainly involved in livestock and agricultural activities, they face many challenges, including a lack of access to the market, inadequate skills, illiteracy, droughts, and financial problems [11]. To overcome these problems, it requires proper identifications of the poor including their characteristics and survival strategies [12].

\section{METHOD}

This research employs qualitative approach, in which data and information have been collected using in-depth interview and analyzed qualitatively. The analytical method used is descriptive analysis that can provide a comprehensive picture of the object and subject of research. In addition, analytical methods used are SWOT analysis to formulate proper strategies to overcome poverty problems by utilizing local resource management.

Data and information have collected from $15 \mathrm{key}$ informants consisting of 6 coconut shell briquette charcoal businessmen, 3 coconut farmers, 2 people from university, 2 people from government institutions, 2 people from non-government organization.

\section{RESULTS}

Previous studies have pointed out that to generate competitive advantage, local resources should be managed in a professional way [13]. The results of this study shows that some aspects of local resources management facing some strategic issues. These issues are, first, financial resources: people who live in rural area and mostly are very poor, they have opportunity to earn more income. On the other hand, they find difficulties to get an access to capital sources. Second, physical resources: low level of processing method and technology used to produce coconut shell briquette charcoal, continuity to obtain raw materials. Third, knowledge: high experience of family business, low formal education, limited training to develop human resource. Fourth, relationships: limited access to suppliers, customers, government, and investors. Based on identification of internal and external factor analysis, matrix of SWOT can be presented as Table 1.

Based on analysis of internal and external factor analysis, eleven alternative strategies for developing coconut shell charcoal briquette as source of renewable energy have been formulated. When community have opportunity to improve their knowledge by managing their local resources, in this case is coconut, hence they might increase their income and lead to poverty reduction. [14]) who examines positive effect of local asset management on household poverty and vulnerability. Those assets consist of tangible and intangible assets will provide benefits to community if they are well managed. Hence, local resources management will perform greater impact on economic development which in turn increase income and reduce poverty. The pointed out the contribution of local resources to global competition in particular and to strategic management in general. 
This study examines two strategies of SO (Strength-Opportunity) for managing local resources, first strengthening partnership between businessman and government as well as universities, and second regulation to increase value added of the product. In the contrary, there are three strategies of WO (WeaknessOpportunity), first capacity building and small business assistance, second strengthening cooperation with universities to increase the value chain of coconut shell charcoal briquette, and third educate community to develop and use environmentally safe energy.

Furthermore, there are three strategies of ST (Strength-Threat) have been formulated, first capacity building and mentoring of SMEs in business management, second strengthening cooperation with government in term of management of coconut shell, third developing technology used and market information access to national and international market. In addition, strategies of WT (Weakness-Threat) are: first, increasing financial management capability in managing small business, second building business coaching among entrepreneurs, and third increasing the use of appropriate technology in the management of briquettes and shell.

\section{CONCLUSION}

Local resources should be utilized and managed in proper, wise and professional ways. The resources include both tangible and intangible assets such as natural resources, human capital, and relational capital. When local resources are well managed, the product can compete in the markets, not only in domestic markets but also in global markets.

This study points out four suggested strategies to reduce poverty utilizing management of local resources: first, strengthening partnership between businessman and government as well as universities, second, developing technological use and market information access to national and international market, third, capacity building and small business assistance, and fourth increasing financial management capability in managing small business, business coaching among entrepreneurs, and regulation to increase value added of the product.

\begin{tabular}{|c|c|c|}
\hline Internal Factors & Strength (S) & Weakness (W) \\
\hline External Factors & $\begin{array}{l}\text { - Strong sociocultural of community } \\
\text { - Abundant raw materials } \\
\text { - Strong ability to adapt business } \\
\text { environment } \\
\text { - Continuity of raw materials } \\
\text { (coconut) } \\
\text { - Family business experience }\end{array}$ & $\begin{array}{l}\text { - Limited access to customers and } \\
\text { suppliers } \\
\text { - Low level of education } \\
\text { - Lack of skill and business management } \\
\text { - Limited knowledge of technology } \\
\text { - Inadequate processing tools to produce } \\
\text { coconut charcoal briquettes } \\
\text { - Many small entrepreneurs are not } \\
\text { bankable }\end{array}$ \\
\hline Opportunities $(\mathrm{O})$ & Strategy SO & Strategy WO \\
\hline $\begin{array}{l}\text { - Regulations of regional government } \\
\text { that encourage SMEs } \\
\text { - The technology required is not } \\
\text { difficult to adopt } \\
\text { - Opportunity for local community to } \\
\text { earn more revenue } \\
\text { - Potential market both domestic } \\
\text { market and international market } \\
\text { - Opportunity to build relationships } \\
\text { with universities } \\
\text { - Opportunity to get supporting fund } \\
\text { namely "people business credit } \\
\text { program" for SMEs }\end{array}$ & $\begin{array}{l}\text { 1. Strengthening partnership } \\
\text { between businessman and } \\
\text { government as well as } \\
\text { universities } \\
\text { 2. Regulation to increase value } \\
\text { added of the product }\end{array}$ & $\begin{array}{l}\text { 1. Capacity building and small business } \\
\text { assistance } \\
\text { 2. Strengthening cooperation with } \\
\text { universities to increase the value chain } \\
\text { of coconut shell charcoal briquette } \\
\text { 3. Educate community to develop and use } \\
\text { environmentally safesource of energy }\end{array}$ \\
\hline Threat (T) & Strategy ST & Strategy WT \\
\hline $\begin{array}{l}\text { - Access to the capital is difficult } \\
\text { - The formation of shell charcoal } \\
\text { business associations has not } \\
\text { established yet } \\
\text { - The scheme of government } \\
\text { cooperation has not been exist } \\
\text { - Business management of a wide } \\
\text { scale is still weak } \\
\text { - Demand of whole coconut sales } \\
\text { (coconut is raw material type, } \\
\text { there is no value added) }\end{array}$ & $\begin{array}{l}\text { 1. Capacity building and mentoring } \\
\text { of SMEs in business management } \\
\text { 2. Strengthening cooperation with } \\
\text { government in term of } \\
\text { management of coconut shell } \\
\text { 3. Developing technology used and } \\
\text { market information access to } \\
\text { national and international market }\end{array}$ & $\begin{array}{l}\text { 1. Increasing financial management } \\
\text { capability in managing small business } \\
\text { 2. Building business coaching among } \\
\text { entrepreneurs } \\
\text { 3. Increasing the use of appropriate } \\
\text { technology in the management of } \\
\text { briquettes and shell }\end{array}$ \\
\hline
\end{tabular}




\section{REFERENCES}

[1] Barney. Is the Resouce Based View a Useful Perspective for Strategic Management Research? Yes., Academy of Management Review, 26 (1), 41-56. 2001.

[2] Biedenbach and Müller,. Absorptive, Innovative, and Adaptive Capabilities and Their Impact on Project and Project Portfolio Performance. International Journal of Project Management. 621-635. 2012.

[3] Collis, D. J. A resource-based analysis of global competition: The case of the bearings industry, Strategic Management Journal, 12(Summer Special Issue): 49-68. 1991.

[4] Domfeh, Bawole. Localising and Sustaining Poverty Reduction: Experiences From Ghana", Management of Environmental Quality: An International Journal, 490-505. 2009.

[5] Elijah, O and Ogunlade, I. Analysis of the uses of information and communication technology for gender empowerment and sustainable poverty alleviation in Nigeria, International Journal of Education \& Development Using ICT, 2/3. 1-25. 2006.

[6] Galunic \& Rodan, Teece, Resource Recombinaions in the Firm: Knowledge Structures and the Potential for Schumpeterian Innovation. Strategic Management Journal .1193-1201. 1997.

[7] Hitt, M.A,. R.D., Ireland \& R.E., Hoskisson. Strategic management: Competitiveness and globalization: Concepts. Ninth Edition.USA: South-Western Cengage Learning. 2011.
[8] Moser, C. The asset vulnerability framework: Reassessing urban poverty reduction strategies, World Development, 26(1), 1-19. 1998.

[9] Pearce II JA, Robinson R B. Strategic Management: Formulation, Implementation, and Control (12 ${ }^{\text {th }}$ edition). McGraw-Hill/Irwin, New York. 2001.

[10] Powell, T. C. Strategic planning as competitive advantage, Strategic Management Journal, 13, 551-558. 1992.

[11] Priem, R. L., and J. E. Butler. "Is the ResourceBased "view" a Useful Perspective for Strategic Management Research?" Academy of Management Review, 26 (1), 22-40. 2011.

[12] Priem, R. L., and J. E. Butler."Is the ResourceBased "view" a Useful Perspective for Strategic Management Research?" Academy of Management Review, 26 (1), 22-40. 2011.

[13] Rahimi, R.A.F. Towards community empowerment for poverty reduction in rural Afghanistan, Journal of Asia Pacific Studies, 34, 33-42. 2015.

[14] Rindova, V. P., and Fombrun, C.J..Constructing competitive advantage: The role of firmconstituent interactions.Strategic Management Journal, 20, 691-710. 1999.

[15] Yang, C., Marlow, P., and Luc, C. Knowledge Management Enablers in Line Shipping, Transportation Research. 45, 893-903. 2009.

[16] Yasemin, Y., Foss, N., Klein, P. and Mahoney, J. Entrepreneurship, Subjectivism, and the Resource-Based View: Toward a New Synthesis, Social Science Electronic Publishing Inc, Copenhagen Business School, Denmark. 2006 